\title{
INOVASI PENGELOLAAN HAMA KEONG MAS (Pomacea canaliculata LAMARCK) MENJADI PRODUK KERIPIK KEONG MAS POLITA DI CV POLITA NUSANTARA
}

\section{Management Innovation of Golden Apple Snail (Pomacea canaliculata Lamarck) becomes Keong Mas Polita Chips Product in CV Polita Nusantara}

\author{
Sulthan Alfathir ${ }^{\star}$, Teti Estiasih \\ Jurusan Teknologi Hasil Pertanian, FTP Universitas Brawijaya Malang \\ Jl. Veteran Malang 65145 \\ Penulis Korespondensi, Email: sulthan_alfathir@yahoo.com
}

\begin{abstract}
ABSTRAK
Keong Mas(Pomacea canaliculata Lamarck) Polita memiliki 4 varian rasa yaitu Rasa Ekstra Pedas, Rasa Balado, Rasa Barbeque dan rasa original. Setiap 100 gram produk keripik keong mas Polita mengandung Karbohidrat 52,06 gram, Lemak 15,01 gram dan protein 22,0 gram, diharapkan ini mampu menjadi nilai tambah dalam produk ini. Dalam pelaksanaan kegiatan produksi Keripik Keong Mas Polita dilakukan tim produksi sesuai Standard Operational Procedure (SOP) yang disusun oleh perusahaan mulai tahap penerimaan bahan baku, penanganan bahan baku, persiapan produksi, pencucian, proses pengirisan, pembuatan bumbu, pencampuran adonan, pencampuran tepung, penggorengan, penirisan minyak, hingga proses pengemasan produk. Perusahaan ini memiliki kapasitas rata-rata 700 pack perbulan mampu menghasilkan omset penjualan perbulan pada kisaran Rp 4.500.000 hingga Rp 5.400.000. Dalam sistem perkembangan pemasaran memiliki 4 orang agen, 10 reseller dan 14 outlet yang tersebar di seluruh wilayah Indonesia. Pembuatan produk ini membantu petani meningkatkan produktvitas hasil pertanian, pemberdayaan masyarakat, menemukan produk inovasi dan mengangkat nilai jual produk lokal.
\end{abstract}

Kata kunci: hama pertanian, keripik Polita, profit usaha, socioentrepreneurship

\section{ABSTRACT}

Keong Mas(Pomacea canaliculata Lamarck) Polita chips have four variants namely extra spicy, balado, barbeque and original flavor. By using a material high in nutrients (protein, carbohydrates, magnesium, vitamin $A$, iron, and phosphorus), this product also capable to suppress the body's cholesterol levels. In the production of Keong Mas Polita Chips, the production team follow the Standard Operating Procedure (SOP) that prepared by the company. It is begin by the stages of acceptance of raw materials, raw material handling, production preparation, leaching, the process of slicing, manufacture seasoning, mixing dough, mixing flour, frying, draining the oil, until packaging process. The company has an capacity of 700 pcs per month that is able to generate monthly sales in the range of $R p 4.5$ million to $R p 5.4$ million. Thus, the company net profit ranging between $R p$ 1.500.000,00 to Rp 2,200,000.00 per month. Nowadays, the company has four agents, 10 resellers and 14 outlets across Indonesia. It petrified farmers increase the productivity of agriculture, community development, finding product innovation and boost the value of local products.

Keywords: agricultural pest, business profit, Polita chips, socioentrepreneurship 


\section{PENDAHULUAN}

Dari tahun ke tahun jumlah hasil produksi pertanian di Jawa Timur tercatat mengalami penurunan yang cukup signifikan. BPS (2014) Jawa Timur menunjukkan bahwa tahun 2014 hasil produktifitas pertanian khususnya padi di Jawa Timur mengalami angka penurunan $1.98 \%$ atau 1.41 juta ton dibandingkan tahun 2013. Fenomena ini disebabkan oleh beberapa faktor antara lain penurunan jumlah lahan pertanian, tingginya hama pertanian dan iklim yang kurang menentu. Salah satu hama pertanian yang jumlahnya sangat tinggi adalah keong mas (Pomacea canaliculata L.). menyatakan bahwa dalam $100 \mathrm{~m}^{2}$ lahan sawah terdapat kurang lebih 100 kilogram keong mas. Di sisi lain, keong sawah mengandung racun jenis neurotoxin pada bagian di dalam dagingnya dan telur. Petani membiarkan keong-keong ini di pematang sawah sebagai salah satu cara memberantasnya. Permasalahan tersebut harus dicarikan solusi secepatnya untuk menanggulangi penurunan produksi dan kerugian yang dialami petani.

Gaya hidup masyarakat yang semakin modern juga ikut mendorong masyarakat cenderung lebih menyukai makanan instan dan sehat. Kebiasaan lain yang banyak ditemui kalangan mahasiswa adalah memakan camilan praktis, hiegenis dan unik. Peluang-peluang yang bisa dibidik lainnya adalah para wisatawan yang berkunjung di suatu daerah membutuhkan produk oleh-oleh khas daerah, namun faktanya dalam daerah tersebut kurang ada variasi jenis produk sebagai ciri khasnya..

Selain itu, terdapat permasalahan yang sangat klasik di Negara ini, yakni pengangguran. Suryamin (2016) mengatakan tingkat pengangguran terbuka pada Februari 2016 mencapai 7.02 juta orang atau 5.5 persen. Dari pengalaman lapang dan melihat peluang yang tersebut, maka dilakukan usaha dalam melakukan inovasi pemanfaatan hama keong mas menjadi produk olahan pangan fungsional yang memiliki rasa enak dan bergizi dengan nama Keripik Polita.

Tujuan dari penyusunan tugas akhir ini adalah meningkatkan volume penjualan produk dan profit usaha, memaksimalkan potensi sumber daya lokal, membuka lapangan pekerjaan baru dan memberdayakan masyarakat dalam bidang usaha socioentrepreneurship

\section{Alat dan Bahan}

\section{BAHAN DAN METODE}

Peralatan yang dibutuhkan proses produksi adalah mesin blender, saringan, cutter, bak, pisau, ember kecil, talenan, alat penyaring, wajan, sutil, toples besar, mesin sealer, spinner, kulkas, box penyimpanan, penggaris, kompor dan tabung LPG. Sedangkan perlengkapan untuk kegiatan produksi adalah clemek, sarung tangan, dan serbet. Bahan yang perlu disiapkan adalah Bahan baku daging keong mas, bawang putih, merica, kemiri, daun jeruk, tepung beras, tepung tapioka, plastik roll dan minyak goreng. Masing-masing mesin dan peralatan tersebut membutuhkan jumlah air pencuci yang berbeda. Bangunan rumah produksi menggunakan instalasi listrik berkapasitas 1300 Watt.

\section{Metode Produksi}

Dalam pelaksanaan produksi produk Keripik Keong Mas Polita dilakukan tim produksi sesuai Standard Operational Procedure (SOP) yang disusun oleh perusahaan mulai tahap penerimaan bahan baku, penanganan bahan baku, persiapan produksi, pencucian, proses pengirisan, pembuatan bumbu, pencampuran adonan, pencampuran tepung, penggorengan, penirisan minyak, hingga proses pengemasan produk.

Proses penerimaan dan penanganan bahan baku di lokasi supplyer. Bahan baku yang didapatkan berupa komoditas keong mas mentah dengan kondisi bercangkang. Bahan baku ini didapatkan dari supplier atau pasar ikan Lamongan. Proses perebusan bertujuan untuk memudahkan proses pengambilan dan pemisahan daging keong dari cangkangnya. Dalam proses ini dilakukan dengan merebus keong mas dengan air yang telah mendidih dan 
pencampuran dengan air kapur $\left(\mathrm{CaCl}_{2}\right)$ yang bertujuan untuk melarutkan lendir keong mas dan membentuk konsistensi atau tingkat kepadatan daging yang dihasilkan dari proses perebusan.

Tahap Pencucian Bahan baku dilakukan dengan sistem batch dengan tempat menyerupai ember yang berlubang. Proses pembilasan dengan air minimal dilakukan sebanyak tiga kali dalam sekali proses yang dilakukan. Proses ini dilakukan maksimal 2 jam setelah bahan baku datang dari supplyer atau pasar.

Pengirisan dilakukan untuk membentuk ukuran daging yang lebih kecil dan lebar sehingga produk mampu tetap kering dan renyah. Satu daging umumnya bisa diiris menjadi 11-15 bagian irisan. Proses pengirisan disesuaikan dengan bentuk daging, sehingga para pegawai pengiris harus mampu memilih cara pengirisan bagian daging agar menciptakan irisan tipis dan memiliki luas permukaan lebar. Pada proses ini juga terdapat Critical Control Point yaitu pengambilan racun dari bagian keong mas.

Pada Proses pembuatan bumbu terdapat dua jenis bumbu yaitu bumbu basah dan bumbu kering. Untuk menjaga kesesuaian resep dan konsistensi rasa kami menggunakan Timbangan digital untuk menentukan berat dari setiap jenis komposisi bahan yang akan digunakan. Sehingga mampu dihasilkan kualitas rasa yang seragam dan tetap dari setiap produksi yang lakukan, ini juga termasuk dalam pengendalian mutu/quality control produk. Bumbu basah terdiri dari bawang putih, jahe, kunir, kemiri, dan daun jeruk. Sedangkan untuk bumbu kering terdiri dari merica ketumbar dan garam. Masing-masing bumbu mengalami proses penghalusan dan pencampuran dalam mesin blender yang berbeda. Untuk penggilingan dan penghalusan bumbu basah biasanya ditambahkan air untuk mempermudah prosesnya.

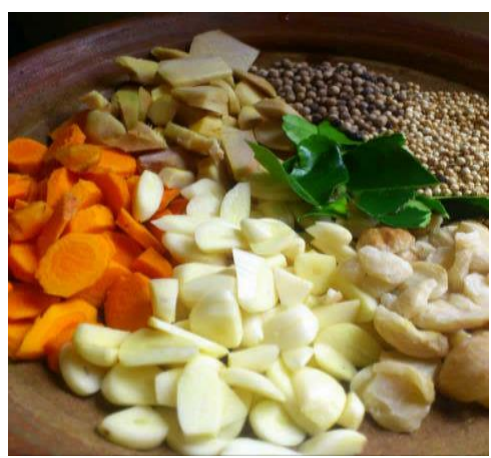

Gambar 1. Bumbu-Bumbu

Pencampuran antara daging irisan dan bumbu dilakukan dalam tempat penampungan yang berkapasistas sekiar 5 kilogram bahan. Pencampuran bumbu dilakukan secara bertahap melalui 3 tahapan penuangan bumbu dilanjutkan pengadukan manual. Ini dilakukan agar bumbu mampu tercampur merata dan meresap ke dalam daging secara keseluruhan.

Sebelum masuk proses penggorengan daging yang telah dibumbui tadi dicampur dengan tepung pada proses penepungan. Tepung yang gunakan adalah tepung beras dan tepung tapioka.

Penggorengan dilakukan dalam sekali proses dengan kondisi api sedang dan jenis metode deep frying. Fungsi dari penggorengan pada proses adalah untuk meningkatkan kualiatas penerimaan konsumen terhadap sensoris produk, menciptakan tekstur yang renyah dan kering serta meningkatkan daya cerna produk

Proses penirisan minyak dilakukan dengan menggunakan mesin Spinner. Proses ini menerapkan teknologi Sentrifugal Force Finishing. Prinsip kerjanya yaitu bahan berminyak yang diletakkan di dalam keranjang bahan akan diputar oleh poros yang dihubungkan dengan motor listrik menggunakan V-Belt. Akibat dari gaya sentrifugal yang terjadi saat keranjang berputar, maka bahan akan bergerak menuju kesisi-sisi keranjang. Bahan yang ukurannya lebih kecil 
daripada ukuran lubang keranjang termasuk minyak, akan bergerak keluar melewati keranjang dan jatuh di body spinner yang selanjutnya mengalir keluar dari body karena kemiringan alas body spinner (Anonim, 2012).

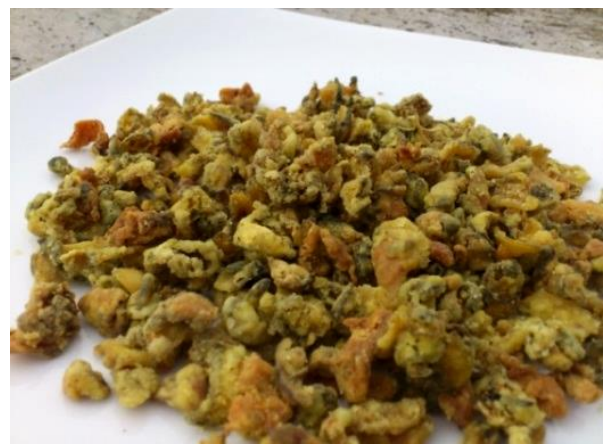

Gambar 2. Hasil Produk setelah Penirisan Minyak

Penerapan teknologi pada proses pengemasan adalah penggunaan mesin Semi Automatic Continous Sealer atau manual hand sealer. Mesin ini bertujuan untuk meniupkan udara dan menseal kemasan plastik produk, sehingga kemasan akan menggelembung. Dalam proses distribusi produk perusahaan menggunakan Box plastik besar yang bisa diangkut menggunakan sepeda motor untuk wilayah pemasaran Lamongan dan Babat. Sedangkan untuk wilayah lain sebagai jangkauan pemasaran online melalui jasa pengiriman barang. Berikut adalah diagram alir proses produksi produk :

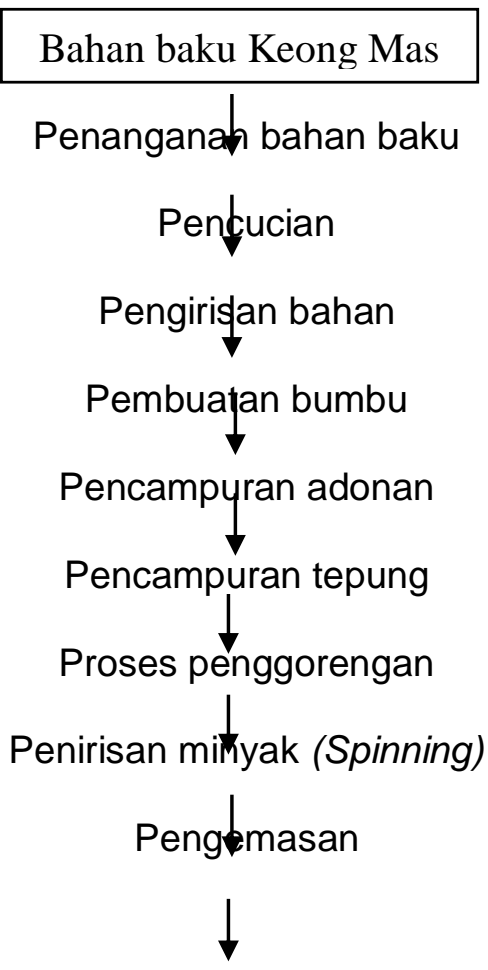

Gambar 3. Diagranh Alir Proses Produksi

Produk Keripik Keong Mas Polita 


\section{HASIL DAN PEMBAHASAN}

\section{Inovasi Produk}

Keripik keong mas polita merupakan produk olahan pangan fungsional yang berbahan dasar Keong Mas (Pomacea canaliculata Lamarck) berspesialisasi ke camilan krispy yang memiliki rasa gurih, lezat dan kering dalam setiap gigitannya. Keripik Keong Mas Polita memiliki 4 varian rasa yaitu Rasa Ekstra Pedas, Rasa Balado, Rasa Barbeque dan rasa original. Setiap $100 \mathrm{gram}$ produk keripik keong mas Polita mengandung Karbohidrat 52,06 gram, Lemak 15,01 gram dan protein 22,0 gram, diharapkan ini mampu menjadi nilai tambah dalam produk ini.
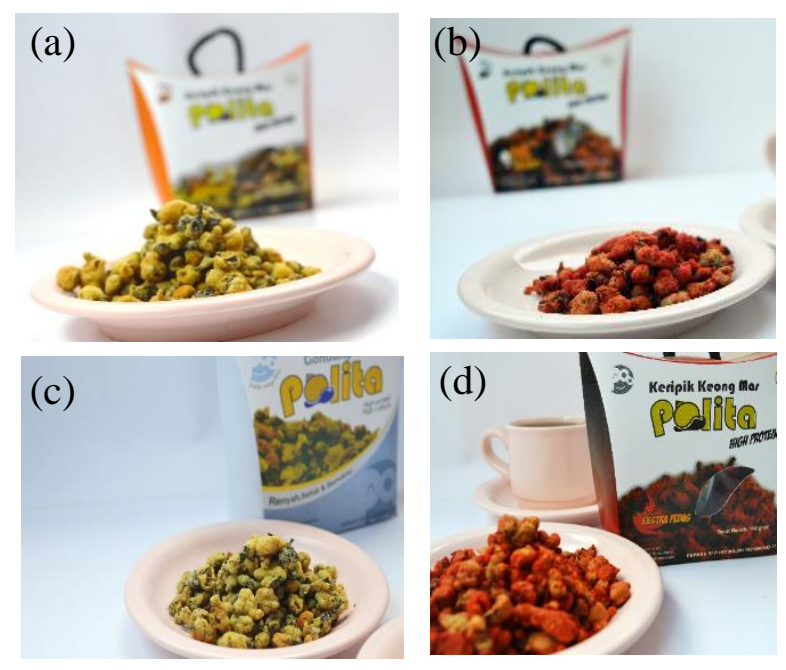

Gambar 4. Keripik Keong Mas Polita (a) Rasa Barbeque (b) Rasa Balado (c) Rasa Original (d) Ekstra Pedas

Berikut ini adalah kandungan nutrisi (nutrition fact) dari produk keripik keong mas Polita.

Tabel 4.1 Informasi Nilai Gizi Keripik Keong Mas Polita

\begin{tabular}{lcc}
\hline Parameter & \multicolumn{2}{l}{ Takaran saji $:$ : 70 gram } \\
& Kalori & $: 302$ \\
& Kalori Lemak: 95 & \\
\cline { 2 - 3 } & \multicolumn{1}{c}{ Berat } & $\%$ AKG $^{*}$ \\
\hline Lemak Total & $10.51 \mathrm{~g}$ & 16.16 \\
Protein & $15.46 \mathrm{~g}$ & 30.93 \\
Karbohidrat Total & $36.44 \mathrm{~g}$ & 12.16 \\
Air & $1.87 \mathrm{~g}$ & - \\
Abu & $5.72 \mathrm{~g}$ & - \\
\hline
\end{tabular}

*) Persen Angka Kecukupan Gizi (AKG) berdasarkan pada diet 2000 kkal. 


\section{Keuangan}

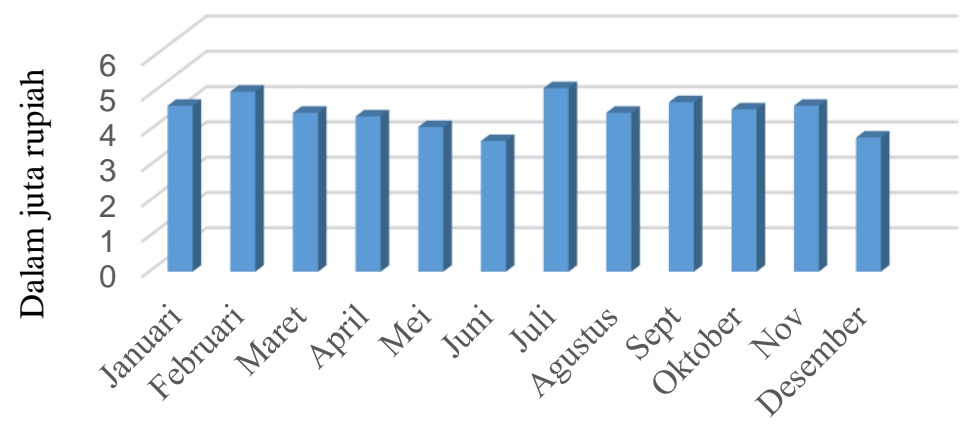

Gambar 5. Grafik Omset Penjualan 2016

Perusahaan ini memiliki kapasitas 700 pcs perbulan mampu menghasilkan omset penjualan perbulan pada kisaran Rp 4.500.000 hingga Rp 5.400.000. Sehingga dengan kondisi tersebut, perusahaan mendapatkan keuntungan bersih 30 - 35 persen dari penjualan yaitu berkisar antara Rp 1.500.000,00 hingga Rp 2.200.000,00 perbulan. Progres penjualan yang tertinggi berada pada varian rasa Keripik Polita Ekstra Pedas, dan terendah pada penjualan produk varian original.

\section{Produksi}

Aktivitas Produksi Keripik Keong Mas Polita dilakukan 3 hari setiap minggu atau 12 kali dalam satu bulan. Para pegawai produksi melakukan semua aktivitas produksi sesuai dengan Standard Operational Procedure (SOP) Perusahaan yang telah dibuat. SOP yang dibuat meliputi dari proses penerimaan bahan baku, penanganan awal, persiapan produksi, proses pencucian, pemanasan awal, prses pengirisan, proses pembuatan bumbu, pencampuran adonan, proses pencampuran tepung, proses penggorengan, proses penirisan minyak dan proses pengemasan. Sistem produksi dilakukan secara batch, yaitu terdiri dari 3 batch tahapan. Batch yang pertama terdiri proses penerimaan bahan baku, penanganan awal, persiapan produksi, proses pencucian, proses pengirisan. Batch kedua adalah prses produksi inti yang terdiri proses pembuatan bumbu, pencampuran adonan, proses pencampuran tepung, proses penggorengan, proses penirisan minyak. Batch ketiga adalah proses pengemasan produk dan penyimpanan.

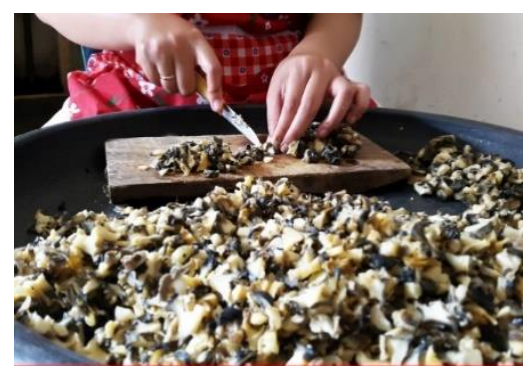

Gambar 6. Proses Pengirisan

Aktivitas jam kerja pada rentang waktu pukul 07.00-15.30. Gaji pegawai produksi dihitung dari aktivitas harian Rp 35.000/hari, sedangkan untuk tenaga pengiris dibayar dengan upah Rp 4.000/kg daging irisan sistem borongan tanpa terikat jam kerja. Saat ini, CV Polita Nusantara memiliki 2 orang pegawai produksi, 1 orang pegawai pengiris dan 1 orang General Manager. 
Kapasistas produksi 700 pack perbulan yang terdiri dari 300 pack rasa ekstra pedas, 150 rasa balado, 200 rasa barbeque dan 50 pack rasa original, perbandingan ini dilihat dari kondisi permintaan pasar terhadap tiap-tiap varian produk yang diproduksi.

\section{Analisa Masalah Dampak Lingkungan}

Limbah hasil samping dari kegiatan produksi Keripik Polita di rumah produksi terbilang kecil yaitu berupa limbah cair pencucian bahan baku dan sanitasi pekerja. Limbah ini alirkan ke bagian aliran selokan diluar lingkungan pabrik. Limbah cair yang dihasilkan tidak berbahaya karena dalam kegiatan proses produksi tidak menggunakan pencampuran bahan kimia berbahaya atau zat beracun, sehingga langsung mengalirkan ke selokan seperti limbah rumah tangga dari masyarakat sekitar.

Limbah padat di bagian supplyer bahan baku yang berupa daging sisa dan cangkang keong digunakan sebagai pakan ikan dan campuran pakan ternak. Cara pengelolaan limbah oleh supplier telah bimbing dan arahkan untuk diolah lebih lanjut, sehingga tidak mencemari lingkungan dan mengganggu masyarakat sekitar.

\section{Utilitas dan Tata Letak}

Air yang diperuntukkan bahan baku dan sanitasi peralatan dan mesin menggunakan pasokan PDAM, sedangkan untuk air sanitasi karyawan dan lingkungan kerja memakai air tanah yang berasal dari sumur dekat pabrik. Pada penanganan bahan baku ini, air digunakan untuk keperluan mencuci Keong Mas. Dalam hal ini digunakan bak atau wadah pencucian dengan diameter $50 \mathrm{~cm}$ dan tinggi $20 \mathrm{~cm}$. Kebutuhan Air dalam sehari adalah 45 liter mulai dari proses pencucian bahan baku, perawatan mesin dan sanitasi pekerja. Sehingga dalam satu bulan perusahaan membutuhkan supply air 540 Liter dalam aktivitas produksi keripik Keong Mas Polita.

Peralatan yang dibutuhkan proses produksi adalah mesin blender, saringan, cutter, bak, pisau, ember kecil, talenan, alat penyaring, wajan, sutil, toples besar, mesin sealer, spinner, kulkas, box penyimpanan, penggaris, kompor dan tabung LPG. Bangunan rumah produksi menggunakan instalasi listrik berkapasitas 1300 Watt. Denah tata letak rumah produksi di CV Polita Nusantara disajikan pada Gambar 7.

\section{Pemasaran Produk}

Dalam sistem perkembangan pemasaran memiliki 4 orang agen, 10 reseller dan 14 outlet yang tersebar diseluruh wilayah Indonesia untuk penjualan produknya. Berikut adalah daftar agen, reseller dan outlet penjualan produk perusahaan

Tabel 1. Daftar Pemasaran Produk

\begin{tabular}{|c|c|c|c|}
\hline No & Jenis Pemasaran & Jumlah & Wilayah \\
\hline 1. & Outlet & 14 tempat & $\begin{array}{l}\text { Lamongan, Babat } \\
\text { dan Gresik }\end{array}$ \\
\hline 2. & Agen & 4 orang & $\begin{array}{l}\text { Bogor, Bontang, } \\
\text { Pekalongan dan } \\
\text { Lamongan }\end{array}$ \\
\hline 3. & Reseller & 9 orang & $\begin{array}{c}\text { Surabaya, Malang, } \\
\text { Lamongan, } \\
\text { Ponorogo dan } \\
\text { Depok }\end{array}$ \\
\hline 4. & Website & 1 web & $\begin{array}{c}\text { www.polita } \\
\text { nusantara.com }\end{array}$ \\
\hline 5. & Media Sosial & 4 media & $\begin{array}{l}\text { Instagram, Fanpage, } \\
\text { Twitter dan Path }\end{array}$ \\
\hline
\end{tabular}




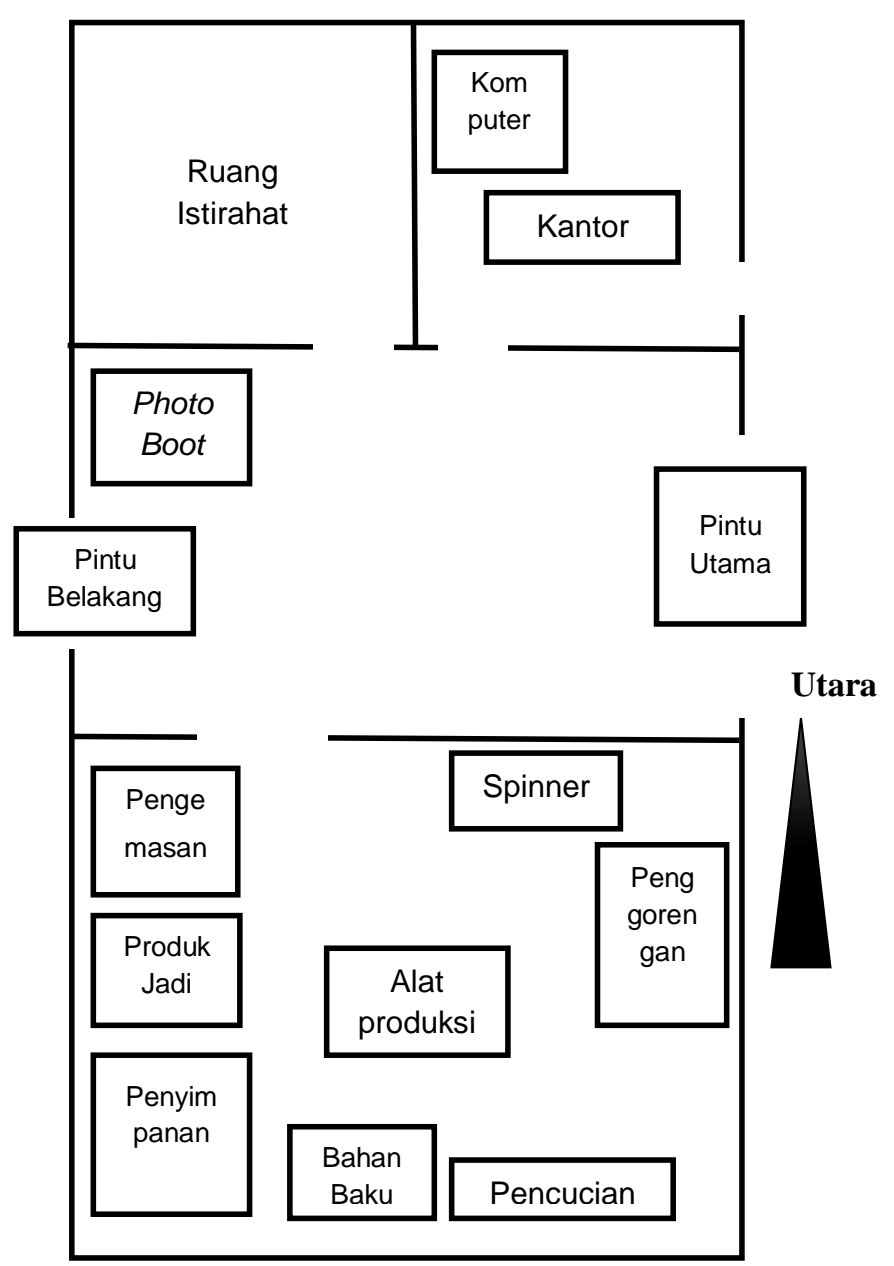

Gambar 7. Tata Letak Rumah Produksi

\subsubsection{Kelayakan Usaha}

Biaya Produksi = Biaya Operasional + Biaya overhead

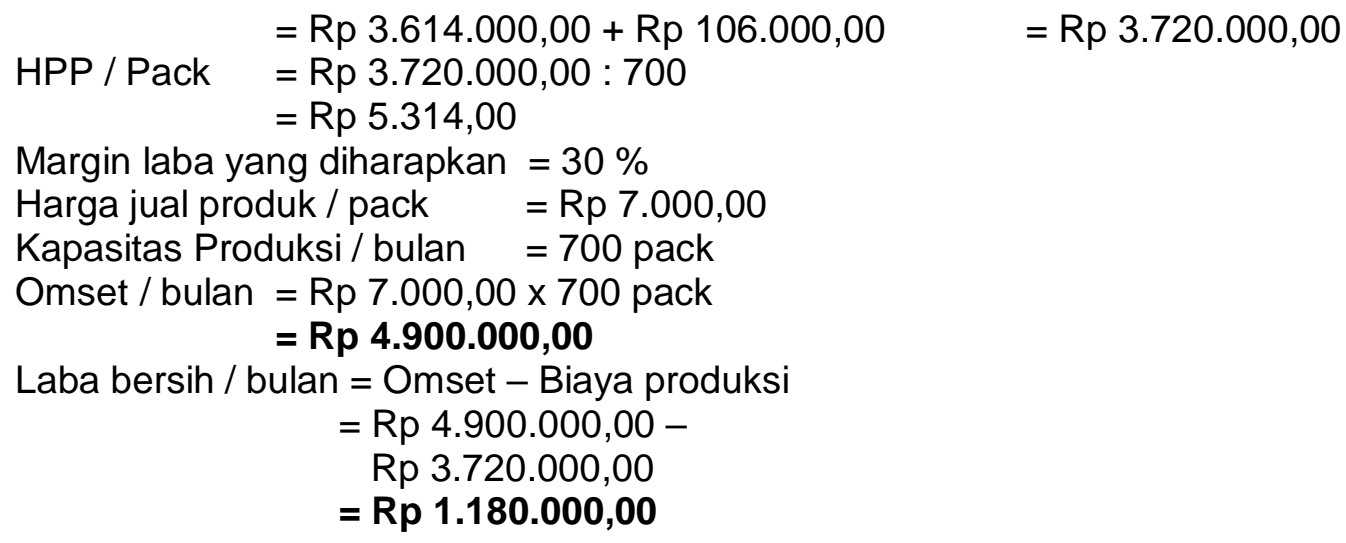




\section{Rencana Pengembangan Usaha}

Dalam komitmen untuk pengembangan produksi Keripik Polita, Perusahaan akan melakukan inovasi dalam hal varian rasa, otomatisasi proses, penambahan supplyer, kemasan produk, produksi pakan dan produk pangan lain yag berbahan baku keong mas.

Pada pengembangan Pengendalian Mutu Usaha akan dilakukan Pembentukan Tim Quality Control (QC) dan Quality Assurance (QA), Audit internal perusahaan, Pembuatan SOP setiap sub bagian produksi, Penerapan sistem Total Quality Management dan HACCP, sertifikasi ISO 9001 dan Sistem Jaminan Halal (SJH).

Bagian keuangan bertanggungjawab terhadap semua transaksi dan kegiatan keuangan usaha yang akan dikembangkan melalui Pencatatan keuangan menggunakan Excel dan Google Drive secara real time, serta membentuk bagian budgeting, bagian penerimaan, bagian pencatatan transaksi, bagian verifikasi dan pembayaran/konsultan pajak.

\section{SIMPULAN}

Keripik keong mas Polita merupakan produk olahan pangan fungsional yang berbahan dasar Keong Mas (Pomacea canaliculata Lamarck) berspesialisasi ke camilan krispy yang memiliki rasa gurih, lezat dan kering dalam setiap gigitannya. Dalam pelaksanaan kegiatan produksi Keripik Keong Mas Polita dilakukan tim produksi sesuai Standard Operational Procedure (SOP) yang disusun oleh perusahaan mulai tahap penerimaan bahan baku, penanganan bahan baku, persiapan produksi, pencucian, proses pengirisan, pembuatan bumbu, pencampuran adonan, pencampuran tepung, penggorengan, penirisan minyak, hingga proses pengemasan produk.

Perusahaan ini memiliki kapasitas rata-rata 700 pcs perbulan mampu menghasilkan omset penjualan perbulan pada kisaran Rp 4.500.000,00 hingga Rp 5.400.000,00. Sehingga dengan kondisi tersebut, perusahaan mendapatkan keuntungan bersih berkisar antara Rp 1.500.000,00 hingga Rp 2.200.000,00 perbulan. Dalam sistem perkembangan pemasaran memiliki 4 orang agen, 10 reseller dan 14 outlet yang tersebar diseluruh wilayah Indonesia Saat ini, CV Polita Nusantara memiliki 2 orang pegawai produksi, 1 orang pegawai pengiris dan 1 orang General Manager.

\section{DAFTAR PUSTAKA}

Agustina, W. 2009. Desain Kemasan dan Label Produk Makanan. Kumpulan Modul pelatihan. UPT B2PTTG-LIPI Subang

Agustina, Wawan. 2014. Teknologi Pengemasan, Desain dan Pelabelan Kemasan Produk Makanan. LIPI: Jakarta

Andrian, Krisna. 2013. Uji Toksisitas Ekstrak Eceng Eceng (Monochoria Vaginalis) sebagai Moluskisida Nabati Terhadap Mortalitas keong Mas (Pomaceae Canaliculata L.). Skripsi: Universitas Jember

Anonim. 2016. http: www.etalasebisnis.com/glosarium/1521/pengertian-penjualankonsinyasi.h tml. Diakses 22 Desember 2016

Anonim. 2016. https://www.facebook.com/hans.kul.3/ posts/173002703133253. Diakses 2 November 2016

BPS. 2015. Produksi Padi Tahun 2014. http://www.bumn.go.id/pertani/berita. Diakses 22 Oktober 2016

Cowie, R.H, et al. 2007. What are Apple Snails Confused Taxonomy and Some Preliminary Resolution. PhilRice, Ingnieria DICTUC and FAO. 3-23

Dreaon, et al. 2013. Golden Apple Snaily Toxin. http://journals.plos.org/plosone. Diakses 29 Oktober 2016

Fatkhutozzi. 2016. https://www.facebook.com. Diakses 22 November 2016 
Inovasi Pengelolaan Hama Keong Mas - Alfathir, dkk Jurnal Pangan dan Agroindustri Vol.6 No.1: 80-89, Januari 2018

Hartono, H. 2012. Keong Sawah Hama yang ada Manfaatnya. http://www.hardiyantohartono.com/sekilas/keong-sawahhama-yang-ada- manfaatnya. Diakses 11 Oktober 2016.

Joshi, R.C. 2006. Golden Apple Snail Recipes : Global Advances in Ecology and Management of Golden Apple Snail. PhilRice, Ingnieria DICTUC and FAO, p.537-560

Julianti, E. dan Nurminah, M. 2006. Teknologi Pengemasan. Departemen Teknologi Pertanian, Fakultas Pertanian, Universitas Sumatera Utara.

Murniyati. 2013. Membuat Filet Lele dan Produk Olahannya. Penebar Swadaya: Jakarta

Oktasari, Nastiti. 2014. Pemanfaatan Keong Sawah (Pila Ampullacea) pada Pembuatan Nugget sebagai Alternatif Makanan Berprotein Tinggi. Skripsi: Semarang

Suharto. 2007. Pengenalan dan Pengendalian Hama Tanaman Pangan. Penerbit Andi. Yogyakarta. 120 hal.

Suharto, H. dan N. Kurniawati. 2009. Keong Mas, dari Hewan Peliharaan menjadi Hama Utama Padi Sawah. Balai Besar Penelitian Tanaman Padi: 385-403.

Supraptiningsih, Endang. 2012. Olahan Serba Belut: Kripik Belut dan Aneka Masakan Belut. Ken Soraya: Jakarta

Suryaningrum, Dwi. 2013. Aneka Produk Olahan Lele. Penebar Swadaya: Jakarta

Triyono, A. 2002. Modul Pengemasan Produk Makanan. Kumpulan Modul Pelatihan. UPT B2PTTG-LIPI Subang.

Tyas, Dyah. 2013. Deskripsi Buku 108 Resep Masakan Ayam Populer Praktis dan Lezat. Agro Media Pustaka: Jakarta 